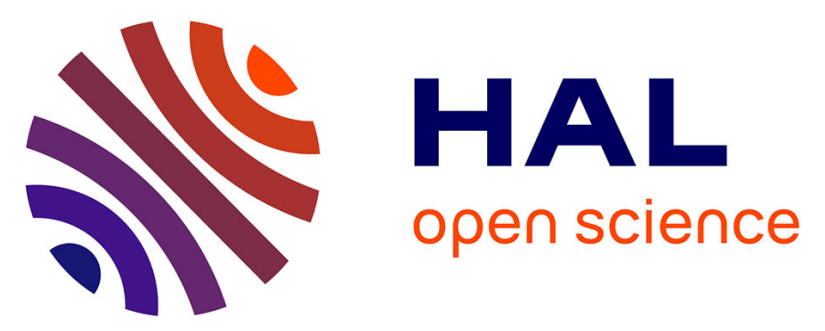

\title{
Impact of climate warming on carbon metabolism and on morphology of invasive and native aquatic plant species varies between spring and summer
}

Morgane Gillard, Gabrielle Thiébaut, Nicolas Rossignol, Solenne Berardocco, Carole Deleu

\section{To cite this version:}

Morgane Gillard, Gabrielle Thiébaut, Nicolas Rossignol, Solenne Berardocco, Carole Deleu. Impact of climate warming on carbon metabolism and on morphology of invasive and native aquatic plant species varies between spring and summer. Environmental and Experimental Botany, 2017, 144, pp.1-10. 10.1016/j.envexpbot.2017.09.009 . hal-01618282

\section{HAL Id: hal-01618282}

https://hal-univ-rennes1.archives-ouvertes.fr/hal-01618282

Submitted on 12 Dec 2017

HAL is a multi-disciplinary open access archive for the deposit and dissemination of scientific research documents, whether they are published or not. The documents may come from teaching and research institutions in France or abroad, or from public or private research centers.
L'archive ouverte pluridisciplinaire HAL, est destinée au dépôt et à la diffusion de documents scientifiques de niveau recherche, publiés ou non, émanant des établissements d'enseignement et de recherche français ou étrangers, des laboratoires publics ou privés. 
Impact of climate warming on carbon metabolism and on morphology of invasive and native aquatic plant species varies between spring and summer

Morgane Gillard ${ }^{\mathrm{a} *}$, Gabrielle Thiébaut ${ }^{\mathrm{a}}$, Nicolas Rossignol ${ }^{\mathrm{a}}$, Solenne Berardocco ${ }^{\mathrm{b}}$, Carole Deleu $^{\mathrm{b}}$

${ }^{a}$ University of Rennes 1, UMR 6553 ECOBIO CNRS, Rennes, France

morgane.gillard35@gmail.com

gabrielle.thiebaut@univ-rennes1.fr

nicolas.b.rossignol@orange.fr

${ }^{\text {b }}$ University of Rennes 1, UMR 1349 IGEPP INRA, Le Rheu, France

carole.deleu@univ-rennes1.fr

solenne.berardocco@univ-rennes1.fr

* Corresponding author: morgane.gillard35@gmail.com

Phone : +33299236809

\section{Highlights}

- $\mathrm{A} 3^{\circ} \mathrm{C}$ increase was applied on two invasive and two native species at two seasons

- The warming induced changes in morphological traits and in carbohydrate contents

- - The growth of the invasive species was particularly stimulated by the warming in spring

- Carbohydrate patterns suggest common physiological mechanisms for the two invasives

- Climate warming may favor the colonisation by invasive species over native species

\section{Abstract}

The rise of global surface temperature by between $1.2^{\circ} \mathrm{C}$ and $4^{\circ} \mathrm{C}$ by 2100 is expected to affect freshwater ecosystems and the growth of aquatic plants. By extending the distribution range of invasive macrophytes, climate warming could increase their management costs. The aim of this study was to test the impact of a $3^{\circ} \mathrm{C}$ warming in spring and in summer on the morphology and physiology 
of two native species (Mentha aquatica, Myosotis scorpioides) and two invasive species (Ludwigia hexapetala, Myriophyllum aquaticum) under controlled conditions. Our study showed that the increase of spring temperature induced morphological modifications for all species, while a $3^{\circ} \mathrm{C}$ warming induced changes in carbohydrates composition for native species in spring, and modification of carbohydrate content for invasive species at both seasons. Patterns of carbohydrate content group the two invasive species together, possibly highlighting common physiological mechanisms. Moreover, the increase of spring temperature favoured the apical and/or lateral growth solely for invasive species. Hence, the invasive species specific response to warming suggests that higher temperature may favour their growth in spring, which might allow them to colonise the water column earlier than natives. This competitive advantage could affect aquatic ecosystems functioning and biodiversity in the coming years.

Keywords: biological invasion; climate change; functional traits; macrophytes; metabolic profiling; photoassimilates

\section{Introduction}

Biological invasions and climate warming are two of the major ecological concerns of the $21^{\text {st }}$ century. In its $5^{\text {th }}$ report, the IPCC estimates that temperatures will increase by between $1.2^{\circ} \mathrm{C}$ and $4^{\circ} \mathrm{C}$ by 2100 (Collins et al., 2013). Impacts of warmer temperatures on ecosystems will be varied (IPCC, 2014) and could promote future biological invasions (Bellard et al., 2013). Invasive species are exotic species that spread widely when growing in their introduced ranges. Their high colonisation capacities can be explained, among other reasons, by their high plasticity to environmental conditions (Walther et al., 2009), by their successful competition abilities (Vilà and Weiner, 2004) or by the release from enemy pressure (Keane and Crawley, 2002). Thus, their geographical range would be expected to increase with increased temperature due to climate change (Bellard et al., 2013; Clements and Ditommaso, 2011). Although challenging, the study of the responses of invasive 
species to climate warming will improve our understanding of their short- or long-term effects on ecosystems. This will help to predict their adaptive strategies.

Many experimental studies have investigated the impact of warmer climates on invasive terrestrial plants (Carón et al., 2015; Verlinden et al., 2014). Aquatic ecosystems are also sensitive to biological invasions and to climate change (Dudgeon et al., 2006; Rahel and Olden, 2008; Sala et al., 2000), but are less studied. Most aquatic invasive plant species form dense mats on the water surface (Hussner, 2009). This intrudes on human activities in aquatic environments, by hampering fishing and swimming in ponds or boat traffic on rivers (Hussner and Lösch, 2007; Zhang and Boyle, 2010). As temperature influences the growth of all plants and productivity of some macrophyte species (Barko et al., 1982; Madsen and Brix, 1997), studying the responses of invasive macrophytes to warmer temperatures is necessary to understand how future climate could increase the invasion risk. Moreover, native species may also benefit from future temperature warming, and improve both their growth and spatial distribution. For example (McKee et al., 2002) showed that for the native Potamogeton natans, flowering occurred earlier in the season and the leaf surface area increased under warming. Nonetheless, as invasive species can invade climate envelopes quite different than those from their area of origin (Gallagher et al., 2010), the introduced populations may differ in their ability to adjust to changing climate. Their plasticity and their local adaptation can confer them a competitive advantage over native species during adaptation to climate warming.

Several authors have highlighted the importance of physiological ecology for a better understanding of climate change impacts on organisms (Bozinovic and Pörtner, 2015; Brunetti et al., 2013; Denny and Helmuth, 2009). Indeed, functional traits are widely used to characterise plant response to climate change (Nicotra et al., 2010), but physiological responses of plants to climate warming are more rarely considered, but mainly by studying the impact of elevated temperature $\left(\approx 40^{\circ} \mathrm{C}\right)$ on crop species (DaMatta et al., 2010). Metabolic profiling analysis represents an opportunity to study physiological responses of organisms by detailed characterisation of plant metabolic responses to 
various environmental perturbations (Lisec et al., 2006). For example, Pagter et al. (2011) highlighted qualitative and quantitative changes in carbohydrates for Hydrangea species in response to temperature. This approach has also been used to study changes induced by abiotic factors on invasive freshwater plant metabolism, revealing a reorientation of the primary metabolism in response to salt stress, especially for carbohydrates (Thouvenot et al., 2015). Thus, metabolic profiling provides a more precise knowledge about the effects of abiotic stress on plants, complementary with functional traits. Furthermore, such an approach generates complex datasets whose the processing and the synthesis constitute a challenge. In the field of biological invasions, metabolomic studies can help to determine potential physiological mechanisms underlying invasion success (Sardans et al., 2011), or at least allow to highlight some specificities of invasive species. For instance, Macel et al. (2014) showed that invasive species of Asteraceae have different and more specific metabolic profiles compared to native species. Comparative responses of native and invasive aquatic plants to increased temperatures have been investigated in a few studies (McKee et al., 2002; Mormul et al., 2012). However, to our knowledge only two studies have combined both morphological trait approaches and metabolic profiling on aquatic plants in order to evaluate an integrated response to abiotic factors (Hussner et al., 2016; Thouvenot et al., 2015). Moreover, according to Peñuelas et al. (2004), plant processes can be more or less sensitive to warming depending on the season, and Silveira and Thiébaut (2017) highlighted that for submersed plant species, a rise of temperature had a greater impact on plant morphological traits in spring than in summer.

In the present study, we used this combined approach to test the effects of an experimental warming of spring and summer mean temperatures on growth and carbon metabolism of four amphibious species. We hypothesised that (i) a $3^{\circ} \mathrm{C}$ warming induces changes on plant morphology and qualitative and/or quantitative modifications of carbohydrate metabolism, (ii) there are more changes due to this temperature increase in spring than in summer, (iii) the induced modifications are different between native and invasive species. 


\section{Materials and methods}

\subsection{Studied species}

Four amphibious species were chosen, two species invasive in Europe (Ludwigia hexapetala, Myriophyllum aquaticum), and two other species native to Europe (Mentha aquatica, Myosotis scorpioides). Some characteristics of these species are summarised in Table 1.

\subsection{Temperature settings}

Temperature settings were based on the maximal monthly temperature (1981-2010) recorded in north western France (data source: Meteo France). The average maximal temperature calculated is $15.7^{\circ} \mathrm{C}$ in spring (March, April, May) and $23^{\circ} \mathrm{C}$ in summer (June, July, August). In our experiments, we applied a $3^{\circ} \mathrm{C}$ warming above current temperatures, based on the future IPCC temperature projections. Thus, four temperatures were selected for two experiments. Experiment 1: $16^{\circ} \mathrm{C}$ (average spring temperature), $19^{\circ} \mathrm{C}\left(3^{\circ} \mathrm{C}\right.$ above average maximal spring temperatures). Experiment 2 : $23^{\circ} \mathrm{C}$ (average summer temperature) and $26^{\circ} \mathrm{C}\left(3^{\circ} \mathrm{C}\right.$ above average maximal summer temperatures).

\subsection{Experimental design}

Young plant of L. hexapetala, M. aquaticum (herafter M. brasiliense), M. aquatica, and M. scorpioides at the same developmental stage were collected in spring (experiment 1) and summer (experiment 2) from the same pond in Brittany, France $\left(48^{\circ} 05^{\prime} 31.3^{\prime \prime} \mathrm{N} ; 01^{\circ} 44^{\prime} 41.3^{\prime \prime} \mathrm{W}\right)$, probably from the same individual. The experiments were conducted in April and June 2014, respectively. Plants were acclimatised for a week in tap water at room temperature. For each species, 20 shoots with apices were cut to $10 \mathrm{~cm}$ lengths. Shoots had no buds or lateral stems. Each shoot was planted in individual containers ( $(\mathrm{x}$ W $\times \mathrm{H}: 8 \times 8 \times 22 \mathrm{~cm}$ ) filled with a substrate composed of $1 \mathrm{~cm}$ of loam (NPK 16-7-15) and $1 \mathrm{~cm}$ of sand. Containers were filled with $150 \mathrm{~mL}$ of tap water i.e. $1 \mathrm{~cm}$ above substrate. Tap water had a moderate nitrogen concentration, low phosphates, high nitrates and was slightly basic 
(average values for tap water: conductivity $=435 \mu \mathrm{S} . \mathrm{cm}^{-1} ; \mathrm{pH} 8.1 ;\left[\mathrm{NO}_{3}{ }^{-}\right]=32.7 \mathrm{mg} \mathrm{L}^{-1} ;\left[\mathrm{PO}_{4}{ }^{3-}\right]<0.02$ $\left.\mathrm{mg} \cdot \mathrm{L}^{-1} ;\left[\mathrm{NO}_{2}^{-}\right]<0.02 \mathrm{mg} \cdot \mathrm{L}^{-1} ;\left[\mathrm{NH}_{4}^{+}\right]<0.03 \mathrm{mg} \cdot \mathrm{L}^{-1}\right)$.

Containers were randomly distributed in two different growth chambers (Percival AR-41L3X) programmed with the chosen temperatures (experiment 1: spring temperatures, $16^{\circ} \mathrm{C}$ and $19^{\circ} \mathrm{C}$; experiment 2: summer temperatures, $23^{\circ} \mathrm{C}$ and $26^{\circ} \mathrm{C}$ ). Within the chambers, light intensity was about $330 \mu \mathrm{mol} . \mathrm{m}^{-2} \cdot \mathrm{s}^{-1}$, with a $12: 12$ photoperiod, and relative humidity was maintained at $75 \%$. Plants were exposed to these conditions for 10 days.

\subsection{Morphological traits}

We measured four morphological traits at the beginning and at the end of the experiment: stem length, fresh weight, number of lateral shoots (buds and ramification) and number of roots. These four traits are linked to functions, the apical growth, the vigour, the lateral growth and the root production, respectively. For each experiment, fresh weight measurements were carried out immediately after removing and cleaning plants from the substrate, and the excess water was blot using paper towel. We considered that plant fresh weight is a global measurement which depict the multiplication or extension of cells, leading either to apical growth, lateral growth, root production, but also to modification of tissue thickness. Thus, we linked plant fresh weight to its vigour. According to Hunt (2003), a relative growth rate $\left(R G R ; d^{-1}\right)$ can be calculated with trait measurements such as length or weight. In this study, calculations for stem and weight RGR were adapted from the RGR calculation of Hunt (1990):

$$
\text { RGR stem }=(\ln L 2-\ln L 1) /(T 2-T 1)
$$

where $L 1$ and $L 2$ represent total length, at time $T 1$ (beginning of the experiment) and T2 (end of the experiment).

$$
\text { RGR weight }=(\ln M 2-\ln M 1) /(T 2-T 1)
$$

where $\mathrm{M} 1$ and $\mathrm{M} 2$ represent the plant's fresh mass respectively at time $\mathrm{T} 1$ and $\mathrm{T} 2$. 


\subsection{Carbohydrate analysis}

At the end of the experiment, the upper five centimetres of each plant were cut. Nine of these apical parts were pooled by species and by temperature conditions by group of three, resulting in three samples per temperature condition for each species. Plant fragments were frozen in liquid nitrogen, stored at $-80^{\circ} \mathrm{C}$, lyophilised and reduced into powder. $10 \mathrm{mg}$ of plant powder were used for each sample, polar components were extracted by a methanol-chloroform-water extraction, and carbohydrates were quantified by GC-MS as described by Thouvenot et al. (2015). $400 \mu \mathrm{L}$ of methanol containing an internal standard ( $20 \mathrm{mM}$ ribitol), $200 \mu \mathrm{L}$ of chloroform and $400 \mu \mathrm{L}$ of water were added successively, after 15 minutes of agitation between each addition. Samples were centrifuged for $5 \mathrm{~min}$ at $13000 \mathrm{~g}, 4^{\circ} \mathrm{C}$. The chloroform phase was discarded, and $50 \mu \mathrm{L}$ of the methanol:water phase was dried using a SpeedVac system. Dried extracts were stored at $-20^{\circ} \mathrm{C}$ until analysis. For GC-MS analysis, vacuum-dried phase aliquots were re-suspended in $50 \mu \mathrm{L}$ of methoxyaminehydrochloride solution in pyridine $\left(20 \mathrm{mg} \cdot \mathrm{mL}^{-1}\right)$. Samples were agitated for $90 \mathrm{~min}$ at $30^{\circ} \mathrm{C}$, and $50 \mu \mathrm{L}$ of $\mathrm{N}$-methyl-N-(trimethylsilyl)trifluoroacetamide were then added; derivatisation was conducted at $37^{\circ} \mathrm{C}$ for 30 min under agitation. Samples were then transferred into glass vials and incubated at room temperature over-night before injection. Metabolite content was estimated in reference to the ribitol signal and dry weight of samples.

\subsection{Statistical analyses}

Statistical analyses were performed using statistical R 3.2.3 software (R Development Core Team, 2015) with packages multcompView and ade4 (Dray and Dufour, 2007). Plots were generated using packages ggplot2 (Wickham, 2009) and factoextra (Kassambara and Mundt, 2016). A two way ANOVA was performed to test the effect of species, temperature and their interaction on functional traits. Pairwise post-hoc comparisons were performed with Tukey HSD test. Normality and homogeneity of variances were tested prior to each parametric test, and data were transformed if necessary by square root or $1 / x$ transformation in order to meet statistical model assumptions. 
We aim at using metabolic profiles to infer physiological patterns of response. However, it is difficult to derive physiological information due to the high number of carbohydrates involved ( $n \geq 20$ in this study). Moreover, part of the information is expected to be redundant as carbohydrates involved in same physiological processes can be interrelated. Methods of dimensionality reduction (Legendre and Legendre, 1998) allow compressing data down to a few important axes of variation (greatly reducing the number of parameters of interest) and help visualising inherent patterns in the dataset. Those methods are commonly used in vegetation ecology where they are applied on data from floristic surveys to derive the environmental gradients underlying plant species distribution (ter Braak and van Tongeren, 1995; Wittaker and Gauch, 1982). Here, we performed a Principal Component Analysis (PCA) on species $x$ carbohydrate content matrix for each temperature regime tested (experiments 1 and 2). Then we examined whether species scores on the first and second PCA axis could be used as a synthetic variable related to species response to temperature. Because in both experiments the first axis mainly represents a species effect, we have chosen to use the second axis as a synthetic variable related to species response to temperature. A two ways ANOVA was finally performed on the mean coordinates of individuals on the selected synthetic variable to test the crossed effects of species and temperature.

We also performed Student's t-tests on total and individual contents in soluble sugars and organic acids, by species, in order to test for quantitative differences induced by temperature treatments.

\section{Results}

\subsection{Effects of a $3^{\circ} \mathrm{C}$ increase of spring temperature (experiment 1)}

\subsubsection{Morphological traits}

Apical and lateral growth varied according to species and temperature interaction (Table 2). Indeed, the two exotic species $M$. brasiliense and L. hexapetala had a significantly higher apical growth at $19^{\circ} \mathrm{C}$ than at $16^{\circ} \mathrm{C}$ (Fig. $\left.1 \mathrm{~A}, \mathrm{~B}\right)$, and L. hexapetala was the only species that produced significantly more lateral shoots in response to the $3^{\circ} \mathrm{C}$ warming, although $M$. aquatica also increased its 
production of lateral shoots with the temperature warming (Table 2). Regardless of the species, the vigour and the root production were higher at $19^{\circ} \mathrm{C}$ than at $16^{\circ} \mathrm{C}$ (Table 2 ).

Our results showed that the growth strategies of the four species were all different (Fig. 1). Regardless of temperature, both native species $M$. aquatica and $M$. scorpioides seemed to favour root production over apical growth, unlike invasive species for which apical growth was more important than root production (Fig. 1C, D). However, M. scorpioides had the highest vigour at $19^{\circ} \mathrm{C}$, while $M$. aquatica had the lowest, and conversely M. aquatica had the highest lateral growth whereas M. scorpioides had the lowest at $19^{\circ} \mathrm{C}$ (Table 2). The lateral growth of $M$. brasiliense was lower than those of $M$. aquatica at $16^{\circ} \mathrm{C}$, and the number of lateral shoots of $M$. scorpioides and $M$. brasiliense was lower than those of M. aquatica and L. hexapetala at $19^{\circ} \mathrm{C}$.

\subsubsection{Metabolic profiles}

The PCA showed that $56.7 \%$ of the carbohydrates were explained by the two first axis (Fig. 2A, B). The contribution of the variables to these axes can be seen in Fig. S1A (Supporting information). A clear opposition was established by the first axis between $M$. aquatica and the three other species (Fig 2A), due to the presence of compounds uniquely in M. aquatica, and of compounds present at $16^{\circ} \mathrm{C}$ and/or $19^{\circ} \mathrm{C}$ in higher concentrations in this species than in the three others (see Table S1). Scores on axis 2 allow the discrimination of the four plant species and appeared also to be sensitive to temperature (Fig. 2B). The ANOVA showed that there was a significant interaction between species and temperature (Table 4). Interestingly, it appeared that the overall composition in carbohydrates was significantly modified by a $3^{\circ} \mathrm{C}$ warming in spring only for the two native species

(Fig. 2E). Thus, native and invasive species were discriminated by two different sets of carbohydrates and the contents of carbohydrates specific to native species tend to increase with higher temperature.

The soluble sugars content (glucose, fructose, saccharose...) was slightly affected by the warming, except for M. brasiliense for which it was significantly lower at $19^{\circ} \mathrm{C}$ (Fig. 3A). However, it appeared 
that when considered individually, the content of some soluble sugars was modified by the temperature treatment: content in fructose decreased for $M$. aquatica, while the content in sucrose increased for M. scorpioides at $19^{\circ} \mathrm{C}$ (Table 5). The content in organic acids, notably of those involved in photorespiration (glycerate, glyoxylate...), increased with the $3^{\circ} \mathrm{C}$ warming in spring only for $L$. hexapetala (Fig. 3B), concomitant with the increase in malate and glycerate content (Table 5). Content in carbohydrates related to raffinose family oligosaccharides (RFO) metabolism (raffinose, galactinol, myo-inositol...) were significantly lower at $19^{\circ} \mathrm{C}$ than at $16^{\circ} \mathrm{C}$ for both invasive species (Fig. 3C). This can be explained by the significantly decrease in galactinol and myo-inositol for $L$. hexapetala and $M$. brasiliense respectively (Table 5). M. aquatica presented a RFO content 3-fold higher than for the other species (Fig. 3C), due to high contents in raffinose, galactose and galactinol.

\subsection{Effects of a $3^{\circ} \mathrm{C}$ increase of summer temperature (experiment 2)}

\subsubsection{Morphological traits}

There was no effect of the $3^{\circ} \mathrm{C}$ warming of summer temperatures on the measured functional traits (Table 3). However, there was significant differences between species for the four traits $(P<0.001$, Table 3), independently of temperatures. M. aquatica had a low apical growth, a low vigour, the highest root production, and high lateral growth. M. scorpioides was characterised by a low apical growth, high vigour, a moderate production of roots, and high lateral growth (Fig. 1). At tested temperatures, L. hexapetala had a high apical growth, a moderate vigour, low production of roots, and high lateral growth. M. brasiliense characteristics were a high apical growth, high vigour, low root production, and the lowest lateral growth.

\subsubsection{Metabolic profiles}

The PCA showed that the two first principal components accounted for $71.8 \%$ of the total variance in carbohydrates content (Fig. 2C, D). The contribution of the variables to these axes can be seen in Fig. S1b. The first axis separated M. scorpioides from the three other species (Fig 2C), which is mainly explained by its high content in sucrose, quinate and malate compared to the three other species, as 
well as the presence of glycolate and cellobiose only in this species (Table S2). However, the PCA showed no separation of individuals by temperature (Fig. 2B). The ANOVA performed confirms that there was no temperature effect, but a strong species effect with a clear discrimination between native and invasive species (Fig 2F, Table 4), invasive species being rather characterised by glycerate and fructose, which were less abundant in native species.

The warming led to a decrease in total soluble sugars content only for the two invasive species (Fig. 3D), explained by a drastic decrease in fructose and glucose content for these species at $26^{\circ} \mathrm{C}$ (Table 5). Otherwise, the temperature increase had no impact on the content in soluble sugars for the two native species (Fig. 3D). Unlike to the warming in spring, the temperature increase in summer had no effect neither on the content in organic acids nor on the content in RFO-related carbohydrates, whatever the species (Fig. 3E, F; Table 5).

\section{Discussion}

The aim of this study was to investigate the impact of a $3^{\circ} \mathrm{C}$ warming in spring and in summer on two invasive (L. hexapetala, M. brasiliense) and two native species ( $M$. aquatica, $M$. scorpioides). We focused on the changes induced by temperature increase on four morphological traits and on carbohydrates content. Primary metabolism to highlight, but also differences between the metabolism or the metabolites composition of invasive and native species, as shown by Macel et al 2014 or Funk et al 2011. We focused on carbohydrates for some of the studied species, these compounds has been shown to react to other abiotic factors (Thouvenot et al). Investigating the metabolic profiles of invasive and native species can allow to better understand the invasiveness of aquatic plant species, and the possible impact/response to future environmental changes.

\subsection{Temperature and seasonal effects}

The growth of both native and invasive species was enhanced by a $3^{\circ} \mathrm{C}$ warming in spring, but none of them was morphologically affected by an increase of summer temperature. Likewise, the quantitative synthetic response of carbohydrates was affected only in spring, especially for the native 
species. However, detailed results focused on single soluble sugar contents showed that they were not only modified in spring, but also in summer, depending on species and on type of carbohydrates. Thus, our first hypothesis in partially validated, a $3^{\circ} \mathrm{C}$ warming induced changes in plant morphology and/or qualitative or quantitative modifications of carbohydrate metabolism.

The qualitative approach showed that the warming applied in spring induced changes in carbohydrate profiles in native species, though changes in detected carbohydrates were mainly due to low carbohydrate contents. The decrease in fructose and glucose contents in $M$. brasiliense when exposed to a $3^{\circ} \mathrm{C}$ warming in spring may reflect a direct allocation of photosynthetates to apices growth more effective at $19^{\circ} \mathrm{C}$ than at $16^{\circ} \mathrm{C}$, an assumption supported by morphological measurements. Surprisingly, except for M. scorpioides, sucrose content was not significantly modified at $19^{\circ} \mathrm{C}$ in the apices of the studied species whereas sucrose is the major transport form of organic carbon in most plants. As an exemple, Havelange et al. (2000) showed that in Sinapis alba, an increase of sucrose content in roots was related to a rise in the amount of sucrose exported by young leaves. Furthermore, it is known that the partitioning of photosynthetates between starch and sugars and is influenced by environmental factors such as temperature, leading to changes in sugars content. For example, Lafta and Lorenzen (1995) showed that in Solanum tuberosum, high temperature induced sucrose accumulation coinciding with decreased starch content in leaves without a change in glucose content. Similar results were observed in our experiment for $M$. scorpioides for which sucrose accumulated at $19^{\circ} \mathrm{C}$ whereas fructose and glucose content was strictly identical at $16^{\circ} \mathrm{C}$ and $19^{\circ} \mathrm{C}$, suggesting that for this species photoassimilates were partitioning.

The higher malate content of $L$. hexapetala at $19^{\circ} \mathrm{C}$ may indicate a stimulation of photosynthetic activity in this C4 species (Madanes et al., 2015) by temperature warming. Photoassimilates may be used for apical and lateral growth, which would be consistent with the observed increase of these morphological traits at $19^{\circ} \mathrm{C}$. Indeed, L. hexapetala was the only species which had both high apical and lateral growth, and is the only one using a C4 photosynthetic 
pathway. Thus, our results suggest that $L$. hexapetala could be classified as a "malate former" among C4 species, with malate being the predominant initial product of photosynthesis (Hatch and Boardman, 2014), which seems to be the case of other C4 macrophytes species as well (Beer and Wetzel, 1982; Bowes et al., 2002). According to Dukes and Mooney (1999) and Sage and Kubien (2007), C4 species might benefit more from warmer temperature than C3 species because of their generally higher optimum temperature for photosynthesis. This suggests that the colonisation by $L$. hexapetala may particularly be favoured by climate warming.

Surprisingly, the content in RFO-related carbohydrates decreased only for both invasive species in response to spring warming. These metabolites accumulate in response to a range of abiotic stress, notably in response to cold stress, in which raffinose might have a protecting effect on chloroplast (Findling et al., 2015). We can hypothesize that $16^{\circ} \mathrm{C}$ could be a sub-optimal temperature for these species and so be perceived as a slight stress. In this case, as at $19^{\circ} \mathrm{C}$ RFO metabolism would be less requested, it can be expected that carbohydrates required for RFO synthesis may be redirected towards biomass production. This could explain the highest apical growth observed for both invasive species at $19^{\circ} \mathrm{C}$.

Despite an unchanged qualitative composition in carbohydrates and an absence of differences in plant growth, the increase of $3^{\circ} \mathrm{C}$ in summer led to a strong decrease in fructose and glucose contents in both invasive species $L$. hexapetala and $M$. brasiliense whereas sucrose content was not modified. If we consider that, as observed for a spring warming, a summer warming stimulates photosynthesis of the invasive species, beneficial effect on carbohydrates production do not necessarily result in greater growth. We can hypothesise that the excess of photoassimilates produced by a more efficient photosynthesis might be allocated to energy storage in starch and/or carbon storage in storage organs. Indeed, recent studies showed that starch content in M. brasiliense was higher in summer than in spring and was preferentially stored in stolons (Wersal et al., 2011). 
Moreover such modification of the carbon partitioning is also a common feature of environmental stress (Rosa et al., 2009).

The present study established that a $3^{\circ} \mathrm{C}$ warming had higher impact on growth and metabolism in spring than in summer, a result consistent with our second hypothesis. This result was expected as spring is the season when these species allocate most of their energy to apical or lateral growth and to nutrients uptake, in order to compete with other species and to survive. In summer they also allocate their energy to sexual reproduction (Stiers et al., 2014; Thouvenot et al., 2013). Moreover, an increase of $3^{\circ} \mathrm{C}$ did not have the same consequences on metabolism at $16^{\circ} \mathrm{C}$ as at $23^{\circ} \mathrm{C}$ : differences in enzyme activities are susceptible to be more important from $16^{\circ} \mathrm{C}$ to $19^{\circ} \mathrm{C}$ than from $23^{\circ} \mathrm{C}$ to $26^{\circ} \mathrm{C}$. The effect of an increase of temperature on plant growth will depend on the period of the year where the warming occurs. It would be interesting to study the impact of a temperature increase on the whole plant life cycle, in order to establish if modifications occurring in spring have an after effect on species spread.

\subsection{Species effect}

Our results showed a strong species effect in both experiments, regardless of the applied temperature. Contrary to the findings of van Kleunen et al. (2010), our results showed that invasive species did not have higher values than native species for traits related to performance. Indeed, regardless of the temperature effect on their growth, the four species developed different growth strategies. Both invasive species favoured apical growth whereas native species allocated energy to the production of roots. Thus, $M$. aquatica and $M$. scorpioides could stay rooted in sediment during flooding events, but may also have a better access to water and nutrients from soil during drawdown, as macrophytes are able to acquire nutrients from both the sediment and water column (Bristow and Whitcombe, 1971; Rattray et al., 1991). In contrast, the low production of roots of $L$. hexapetala and $M$. brasiliense may confer upon them the ability to disperse more easily through water flow, and their high apical growth allows them to outcompete other species for light 
acquisition. Thus, the studied native and invasive species seem to present a trade-off between their regeneration (apical growth) and their colonisation (root production) abilities (Barrat-Segretain et al., 1998). However, lateral growth and general vigour were different within invasive and native species. The high lateral growth of $M$. aquatica could allow individuals to escape from the shadow created by other species. The four species live in the same ecosystems, but each of them adopts its own growth strategy to face competition, resource acquisition and climate events.

The morphological results observed for the two invasive species are consistent with the work of Rejmánková (1992), who showed that creeping emergent species such as Ludwigia peploides and M. brasiliense are characterised by rapid growth and allocation of most biomass and nitrogen into aboveground plant parts. Additionally, invasive species tended to have the same patterns of carbohydrates content in their apical parts, whether in spring or in summer. These invasive species seems to have common physiological characteristics, that might result from a common adaptation to local climate through the selective pressure generated by the invasion process (Lee, 2002), and that favour their high and rapid growth.

As there was no clearly pronounced differences between exotic and native species, we our third hypothesis cannot be confirmed with certainty. Literature data suggest that global warming might induce the dominance of invasive species over natives (Netten et al., 2010), but our results are consistent with this statement only for L. hexapetala, and mostly when the warming occurs in spring. To establish if invasive species would be dominant over native species require to grow them in mixture, especially because allelopathic effects are suspected for L. hexapetala (Dandelot et al., 2008) and M. aquatica (Lovett and Weerakoon, 1983).

In this study, the carbohydrates profiling was performed on apical parts of plants, which allows us mainly to link the carbohydrates profiles to apical growth. Metabolic profiling analysis at the level of the other plant organs than that we studied will be necessary in order to confirm our assumptions on carbon allocation, especially analysis of carbohydrate contents in roots and lateral branches, 
associated with the determination of starch content in the different organs in spring and in summer.

Profiling other metabolites or focusing more specifically on photosynthesis could also bring more information and allow a better understanding of the studied species response to climate warming.

Moreover, temperature is not the only factor that could influence future species distribution, and the combination of multiple component of climate change (alteration of water chemistry and hydrological regimes) could also be studied.

\section{Conclusion}

Our study showed that the impact of a $3^{\circ} \mathrm{C}$ warming on four aquatic plants species were more intense in spring than in summer. In spring, the apical and lateral growth of the two invasive species was particularly affected by a temperature increase. The warming globally improved the vigour and the production of roots of the four freshwater species in spring. Invasive species metabolism was stimulated by a $3^{\circ} \mathrm{C}$ warming in summer, but with no effect on their morphological characteristics. Climate warming might favour the growth of invasive species over native species, especially during spring, with possible repercussion on the entire growing season as well as on plant community composition and on ecosystem functioning.

No difference between invasive and native species can be made with respect to the growth measurement results. However, patterns of contents in carbohydrates group the two invasive species together both in spring and in summer experiments, possibly highlighting common physiological mechanisms explaining their invasiveness. Of the four studied species, L. hexapetala had the most effective apical and lateral growth. Its $\mathrm{C} 4$ photosynthesis seems to confer on it an advantage to colonise water bodies. Although apical and lateral growth of $M$. scorpioides was not enhanced by warming in spring, its high capacity to produce carbohydrates such as sucrose, associated with its increased vigour could allow it to take advantage from climate warming.

This study is a first sketch about the impacts of rising temperatures on the metabolome of native and invasive macrophytes. The use of metabolic profiling to study responses of plant species with no- 
agronomic interest is at its infancy. We showed that this approach reveals differential responses among species, which could be a clue to identify potential mechanisms of invasiveness of alien species. Further investigation about amino acid profiling, gene expression or enzyme activity of invasive plant species could be of broad interest to understand the mechanisms behind their strong proliferation in their exotic ranges, and to study response to biotic and abiotic factors.

\section{Acknowledgements}

We are grateful to Léa Mie, Quentin Hinet and Charlotte Richard for their participation in the traits measurement. We are very thankful to Dennis Webb for the time he kindly dedicated to the English proofreading of this manuscript. This work was supported by a Ph.D. fellowship from the French Ministry for Higher Education and Research to MG.

\section{Authors' contribution}

MG, $C D$ and $G T$ designed the experiment. MG conducted the experiments. MG and CD performed the extraction of polar components. SB performed the GC-MS analyses. MG, CD and NR analysed the data. MG and CD interpreted the data and wrote the manuscript with contributions from all the authors.

\section{References}

Barko, J., Hardin, D., Matthews, M., 1982. Growth and morphology of submersed freshwater macrophytes in relation to light and temperature. Can. J. Bot.

Barrat-Segretain, M.H., Bornette, G., Hering-Vilas-Bôas, A., 1998. Comparative abilities of vegetative regeneration among aquatic plants growing in disturbed habitats. Aquat. Bot. 60, 201-211. doi:10.1016/S0304-3770(97)00091-0

Beer, S., Wetzel, R.G., 1982. Photosynthesis in submersed macrophytes of a temperate lake. Plant Physiol. 70, 488-492. doi:10.1104/pp.70.2.488 
Bellard, C., Thuiller, W., Leroy, B., Genovesi, P., Bakkenes, M., Courchamp, F., 2013. Will climate change promote future invasions? Glob. Chang. Biol. 19, 3740-3748. doi:10.1111/gcb.12344

Bowes, G., Rao, S.K., Estavillo, G.M., Reiskind, J.B., 2002. C4 mechanisms in aquatic angiosperms: comparisons with terrestrial C4 systems. Funct. Plant Biol. 29, 379-392. doi:10.1071/PP01219

Bozinovic, F., Pörtner, H.O., 2015. Physiological ecology meets climate change. Ecol. Evol. 5, 10251030. doi:10.1002/ece3.1403

Bristow, J.M., Whitcombe, M., 1971. The role of roots in the nutrition of aquatic vascular plants. Am. J. Bot. 58, 8-13. doi:10.2307/2441300

Brunetti, C., George, R.M., Tattini, M., Field, K., Davey, M.P., 2013. Metabolomics in plant environmental physiology. J. Exp. Bot. 64, 4011-4020. doi:10.1093/jxb/ert244

Carón, M.M., De Frenne, P., Chabrerie, O., Cousins, S.A.O., De Backer, L., Decocq, G., Diekmann, M., Heinken, T., Kolb, A., Naaf, T., Plue, J., Selvi, F., Strimbeck, G.R., Wulf, M., Verheyen, K., 2015. Impacts of warming and changes in precipitation frequency on the regeneration of two Acer species. Flora 214, 24-33. doi:10.1016/j.flora.2015.05.005

Clements, D.R., Ditommaso, A., 2011. Climate change and weed adaptation: can evolution of invasive plants lead to greater range expansion than forecasted? Weed Res. 51, 227-240.

Collins, M., Knutti, R., Arblaster, H., Dufresne, J.-L., Fichefet, T. Friedlingstein, P. Gao, X., Gutowski, W.J., Johns, T., Krinner, G., Shongwe, M., Tebaldi, C., Weaver, A.J., Wehner, M., 2013. IPCC, 2013: Long-term climate change: projections, commitments and irreversibility. In: Climate Change 2013: The physical science basis. Contribution of working group I to the fifth assessment report of the intergovernmental panel on climate change. Cambridge, New York.

DaMatta, F.M., Grandis, A., Arenque, B.C., Buckeridge, M.S., 2010. Impacts of climate changes on crop physiology and food quality. Food Res. Int. 43, 1814-1823.

doi:10.1016/j.foodres.2009.11.001 
Dandelot, S., Robles, C., Pech, N., Cazaubon, A., Verlaque, R., 2008. Allelopathic potential of two invasive alien Ludwigia spp. Aquat. Bot. 88, 311-316. doi:10.1016/j.aquabot.2007.12.004

Denny, M., Helmuth, B., 2009. Confronting the physiological bottleneck: A challenge from ecomechanics. Integr. Comp. Biol. 49, 197-201. doi:10.1093/icb/icp070

Dray, S., Dufour, A.B., 2007. The ade4 Package: Implementing the Duality Diagram for Ecologists. J. Stat. Softw. 22, 1-20. doi:10.1.1.177.8850

Dudgeon, D., Arthington, A.H., Gessner, M.O., Kawabata, Z.-I., Knowler, D.J., Lévêque, C., Naiman, R.J., Prieur-Richard, A.-H., Soto, D., Stiassny, M.L.J., Sullivan, C.A., 2006. Freshwater biodiversity: importance, threats, status and conservation challenges. Biol. Rev. 81, 163-82. doi:10.1017/S1464793105006950

Dukes, J.S., Mooney, H.A., 1999. Does global change increase the success of biological invaders? Trends Ecol. Evol. 14, 135-139. doi:10.1016/S0169-5347(98)01554-7

EPPO, 2011. Ludwigia grandiflora and L. peploides Onagraceae - Water primroses. EPPO Bull. 41, 414-418. doi:10.1111/j.1365-2338.2011.02511.x

Findling, S., Zanger, K., Krueger, S., Lohaus, G., 2015. Subcellular distribution of raffinose oligosaccharides and other metabolites in summer and winter leaves of Ajuga reptans (Lamiaceae). Planta 241, 229-241. doi:10.1007/s00425-014-2183-2

Gallagher, R. V, Beaumont, L.J., Hughes, L., Leishman, M.R., 2010. Evidence for climatic niche and biome shifts between native and novel ranges in plant species introduced to Australia. J. Ecol. 98, 790-799. doi:10.1111/j.1365-2745.2010.01677.x

Hatch, M.D., Boardman, N.K., 2014. Volume 8: Photosynthesis, in: Stumpf, P.K., Conn, E.E. (Eds.), The Biochemistry of Plants, A Comprehensive Treatise. Academic Press, p. 521.

Havelange, A., Lejeune, P., Bernier, G., 2000. Sucrose/cytokinin interaction in Sinapis alba at floral 
induction: A shoot-to-root-to-shoot physiological loop. Physiol. Plant. 109, 343-350.

doi:10.1034/j.1399-3054.2000.100316.x

Hunt, R., 1990. Basic Growth Analysis: Plant Growth Analysis for Beginners.

Hunt, R., Thomas, B., Murphy, D.J., Murray, D., 2003. Growth analysis, individual plants. Encycl. Appl. Plant Sci. 579-588.

Hussner, A., 2009. Growth and photosynthesis of four invasive aquatic plant species in Europe. Weed Res. 49, 506-515. doi:10.1111/j.1365-3180.2009.00721.x

Hussner, A., Lösch, R., 2007. Growth and photosynthesis of Hydrocotyle ranunculoides L. fil. in Central Europe. Flora 202, 653-660. doi:10.1016/j.flora.2007.05.006

Hussner, A., Mettler-altmann, T., Weber, A.P.M., 2016. Acclimation of photosynthesis to supersaturated CO 2 in aquatic plant bicarbonate users. Freshw. Biol. 61, 1720-1732. doi:10.1111/fwb.12812

Hussner, A., Meyer, C., Busch, J., 2009. The influence of water level and nutrient availability on growth and root system development of Myriophyllum aquaticum. Weed Res. 49, 73-80. doi:10.1111/j.1365-3180.2008.00667.x

IPCC, 2014. Climate Change 2014: impacts, adaptation, and vulnerability. Contribution of working group II to the fifth assessment report of the Intergovernmental Panel on Climate Change. Cambridge University Press, p. 1132.

Kassambara, A., Mundt, F., 2016. factoextra: Extract and visualize the results of multivariate data analyses.

Keane, R.M., Crawley, M.J., 2002. Exotic plant invasions and the enemy release hypothesis 17, 164170.

Lafta, A.M., Lorenzen, J.H., 1995. Effect of high temperature on plant growth and carbohydrate 
metabolism in potato. Plant Physiol. 109, 637-643.

Lee, C., 2002. Evolutionary genetics of invasive species. Trends Ecol. Evol. 17, 386-391. doi:10.1016/S0169-5347(02)02554-5

Legendre, P., Legendre, L., 1998. Numerical ecology : second english edition. Elsevier, Amsterdam.

Lisec, J., Schauer, N., Kopka, J., Willmitzer, L., Fernie, A.R., 2006. Gas chromatography mass spectrometry-based metabolite profiling in plants. Nat. Protoc. 1, 387-396. doi:10.1038/nprot.2006.59

Lovett, J. V., Weerakoon, W.L., 1983. Weed characteristics of the Labiatæ, with special reference to allelopathy. Biol. Agric. Hortic. 1, 145-158. doi:10.1080/01448765.1983.9754388

Macel, M., DeVos, R.C.H., Jansen, J.J., van der Putten, W.H., van Dam, N.M., 2014. Novel chemistry of invasive plants : exotic species have more unique metabolomic profiles than native congeners. Ecol. Evol. 4, 2777-2786. doi:10.1002/ece3.1132

Madanes, N., Quintana, R.D., Kandus, P., Bó, R.F., 2015. Species richness and functional groups of angiosperms from the Paraná River Delta region (Argentina). Check List 11, 1803. doi:10.15560/11.6.1803

Madsen, T. V., Brix, H., 1997. Growth, photosynthesis and acclimation by two submerged macrophytes in relation to temperature. Oecologia 110, 320-327. doi:10.1007/s004420050165

McKee, D., Hatton, K., Eaton, J.W., Atkinson, D., Atherton, A., Harvey, I., Moss, B., 2002. Effects of simulated climate warming on macrophytes in freshwater microcosm communities. Aquat. Bot. 74, 71-83. doi:10.1016/S0304-3770(02)00048-7

Moreira, I., Monteira, A., Ferreira, T., 1999. Biology and control of parrotfeather (Myriophyllum aquaticum) in Portugal. Ecol. Environ. Conserv. 5, 171-179.

Mormul, R.P., Ahlgren, J., Ekvall, M.K., Hansson, L.-A., Brönmark, C., 2012. Water brownification may 
increase the invasibility of a submerged non-native macrophyte. Biol. Invasions 14, 2091-2099. doi:10.1007/s10530-012-0216-y

Netten, J.J.C., Arts, G.H.P., Gylstra, R., van Nes, E.H., Scheffer, M., Roijackers, R.M.M., 2010. Effect of temperature and nutrients on the competition between free-floating Salvinia natans and submerged Elodea nuttalii in mesocosms. Fundam. Appl. Limnol. / Arch. für Hydrobiol. 177, 125-132. doi:10.1127/1863-9135/2010/0177-0125

Nicotra, A.B., Atkin, O.K., Bonser, S.P., Davidson, A.M., Finnegan, E.J., Mathesius, U., Poot, P., Purugganan, M.D., Richards, C.L., Valladares, F., van Kleunen, M., 2010. Plant phenotypic plasticity in a changing climate. Trends Plant Sci. 15, 684-92. doi:10.1016/j.tplants.2010.09.008

Pagter, M., Lefèvre, I., Arora, R., Hausman, J.F., 2011. Quantitative and qualitative changes in carbohydrates associated with spring deacclimation in contrasting Hydrangea species. Environ. Exp. Bot. 72, 358-367. doi:10.1016/j.envexpbot.2011.02.019

Peñuelas, J., Gordon, C., Llorens, L., Nielsen, T., Tietema, A., Beier, C., Bruna, P., Emmett, B., Estiarte, M., Gorissen, A., 2004. Nonintrusive field experiments show different plant responses to warming and drought among sites, seasons, and species in a north-south European gradient. Ecosystems 7, 598-612. doi:10.1007/s10021-004-0179-7

R Development Core Team, 2015. R: A language and environment for statistical computing.

Rahel, F.J., Olden, J.D., 2008. Assessing the effects of climate change on aquatic invasive species. Conserv. Biol. 22, 521-533. doi:10.1111/j.1523-1739.2008.00950.x

Rattray, M.R., Howard-Williams, C., Brown, J.M.A., 1991. Sediment and water as sources of nitrogen and phosphorus for submerged rooted aquatic macrophytes. Aquat. Bot. 40, 225-237. doi:10.1016/0304-3770(91)90060-I

Rejmánková, E., 1992. Ecology of creeping macrophytes with special reference to Ludwigia peploides (H.B.K.) Raven. Aquat. Bot. 43, 283-299. doi:10.1016/0304-3770(92)90073-R 
Rosa, M., Prado, C., Podazza, G., Interdonato, R., González, J.A., Hilal, M., Prado, F.E., 2009. Soluble sugars. Plant Signal. Behav. 4, 388-393. doi:10.4161/psb.4.5.8294

Ruaux, B., 2008. Les plantes envahissantes des corridors fluviaux : traits biologiques, impacts de Ludwigia peploides et L. grandiflora en Loire moyenne et implications pour la gestion. Université François-Rabelais de Tours.

Sage, R.F., Kubien, D.S., 2007. The temperature response of C3 and C4 photosynthesis. Plant, Cell Environ. 30, 1086-1106. doi:10.1111/j.1365-3040.2007.01682.x

Sala, O.E., Chapin III, F.S., Armesto, J.J., Berlow, E., Bloomfield, J., Dirzo, R., Huber-Sanwald, E., Huenneke, L.F., Jackson, R.B., Kinzig, A., Leemans, R., Lodge, D.M., Mooney, H.A., Oesterheld, M., Le Roy Poff, N., Sykes, M.T., Walker, B.H., Walker, M., Wall, D.H., 2000. Global Biodiversity Scenarios for the Year 2100. Science (80-. ). 287, 1770-1774. doi:10.1126/science.287.5459.1770

Sardans, J., Peñuelas, J., Rivas-Ubach, A., 2011. Ecological metabolomics : overview of current developments and future challenges. Chemoecology 21, 191-225. doi:10.1007/s00049-0110083-5

Silveira, M.J., Thiébaut, G., 2017. Impact of climate warming on plant growth varied according to the season. Limnol. - Ecol. Manag. Inl. Waters. doi:10.1016/j.limno.2017.05.003

Stiers, I., Coussement, K., Triest, L., 2014. The invasive aquatic plant Ludwigia grandiflora affects pollinator visitants to a native plant at high abundances. Aquat. Invasions 9, 357-367. doi:10.3391/ai.2014.9.3.10

ter Braak, C.J.F., van Tongeren, O.F., 1995. Ordination, in: Data Analysis in Community and Landscape Ecology. Cambridge University Press, Cambridge, pp. 91-169.

Thiébaut, G., 2007. Invasion success of non-indigenous aquatic and semi-aquatic plants in their native and introduced ranges. A comparison between their invasiveness in North America and 
in France. Biol. Invasions 9, 1-12. doi:10.1007/s10530-006-9000-1

Thouvenot, L., Deleu, C., Berardocco, S., Haury, J., Thiébaut, G., 2015. Characterization of the salt stress vulnerability of three invasive freshwater plant species using a metabolic profiling approach. J. Plant Physiol. 175, 113-121. doi:10.1016/j.jplph.2014.11.007

Thouvenot, L., Haury, J., Thiebaut, G., 2013. A success story: water primroses, aquatic plant pests. Aquat. Conserv. Mar. Freshw. Ecosyst. 23, 790-803. doi:10.1002/aqc.2387

USDA, 2017. Plants profile for Mentha aquatica (water mint) [WWW Document]. URL https://plants.usda.gov/core/profile?symbol=MEAQ

USDA, 2014. Plants profile for Myosotis scorpioides (true forget-me-not) [WWW Document]. URL https://plants.usda.gov/core/profile?symbol=MYSC (accessed 1.1.17).

van Kleunen, M., Weber, E., Fischer, M., 2010. A meta-analysis of trait differences between invasive and non-invasive plant species. Ecol. Lett. 13, 235-45. doi:10.1111/j.1461-0248.2009.01418.x

Verlinden, M., De Boeck, H.J., Nijs, I., 2014. Climate warming alters competition between two highly invasive alien plant species and dominant native competitors. Weed Res. 54, 234-244. doi:10.1111/wre.12076

Vilà, M., Weiner, J., 2004. Are invasive plant species better competitors than native plant species? evidence from pair-wise experiments. Oikos 105, 229-238. doi:10.1111/j.00301299.2004.12682.x

Walther, G.-R., Roques, A., Hulme, P.E., Sykes, M.T., Pyšek, P., Kühn, I., Zobel, M., Bacher, S., BottaDukát, Z., Bugmann, H., Czúcz, B., Dauber, J., Hickler, T., Jarosík, V., Kenis, M., Klotz, S., Minchin, D., Moora, M., Nentwig, W., Ott, J., Panov, V.E., Reineking, B., Robinet, C., Semenchenko, V., Solarz, W., Thuiller, W., Vilà, M., Vohland, K., Settele, J., 2009. Alien species in a warmer world: risks and opportunities. Trends Ecol. Evol. 24, 686-93. doi:10.1016/j.tree.2009.06.008 
Wersal, R.M., Cheshier, J.C., Madsen, J.D., Gerard, P.D., 2011. Phenology, starch allocation, and environmental effects on Myriophyllum aquaticum. Aquat. Bot. 95, 194-199. doi:10.1016/j.aquabot.2011.05.012

Wickham, H., 2009. ggplot2: elegant graphics for data analysis.

Wittaker, R.H., Gauch, H.G., 1982. Evaluation of ordination techniques, in: Ordination of Plant Communities. pp. 279-336.

Zhang, C., Boyle, K.J., 2010. The effect of an aquatic invasive species (Eurasian watermilfoil) on lakefront property values. Ecol. Econ. 70, 394-404. doi:10.1016/j.ecolecon.2010.09.011

\section{Figure legend}

Fig. 1. Functional responses of Ludwigia hexapetala (LUHE), Myriophyllum brasiliense (MYBR), Mentha aquatica (MEAQ) and Myosotis scorpioides (MYSC) to a $3^{\circ} \mathrm{C}$ warming of a spring temperature $(A, B, C, D)$ and of a summer temperature $(E, F, G, H)$. Values represented have been normalised per trait

Fig. 2. Principal component analysis (PCA) on carbohydrate content with a $3^{\circ} \mathrm{C}$ increase of spring temperature $(A, B)$ and of summer temperature ( $C, D)$ for Ludwigia hexapetala (LUHE,), Myriophyllum brasiliense (MYBR), Mentha aquatica (MEAQ,) and Myosotis scorpioides (MYSC). Individuals were grouped by species $(A, C)$ and by temperature $(B, D)$. On panels $B$ and $D$, dots and lines in light grey represent the control temperature $\left(16^{\circ} \mathrm{C}\right.$ or $\left.23^{\circ} \mathrm{C}\right)$ and those in black represent the warmer temperature $\left(19^{\circ} \mathrm{C}\right.$ of $\left.26^{\circ} \mathrm{C}\right)$. Lines link individuals to their respective centroids $(n=6, A, C ; n=24, B, D)$. Refer to Fig. S1 for correlation circles. Barplots in panel (E) and (F) represent a synthetic representation of the qualitative modifications in carbohydrate content depending on temperature, i.e. the mean coordinates of individuals on Axis $2 \pm S E$, at both seasons. Different small letters indicate significantly different interactions between species and temperature (E). Different capital letters represent significant differences between species (F). 
Fig. 3. Total content in soluble sugars, in organic acids and in Raffinose Family Oligosaccharides (RFO) $( \pm S E)$ of Ludwigia hexapetala (LUHE,), Myriophyllum brasiliense (MYBR), Mentha aquatica (MEAQ,) and Myosotis scorpioides (MYSC). at $16^{\circ} \mathrm{C}$ and $19^{\circ} \mathrm{C}(\mathrm{A}, \mathrm{B}, \mathrm{C})$ and at $23^{\circ} \mathrm{C}$ and $26^{\circ} \mathrm{C}(\mathrm{D}, \mathrm{E}, \mathrm{F})$. Stars indicate significant differences between temperature regimes, Student's t-test: ${ }^{*} p<0.05,{ }^{* *} p<0.01$, $* * * p<0.001$

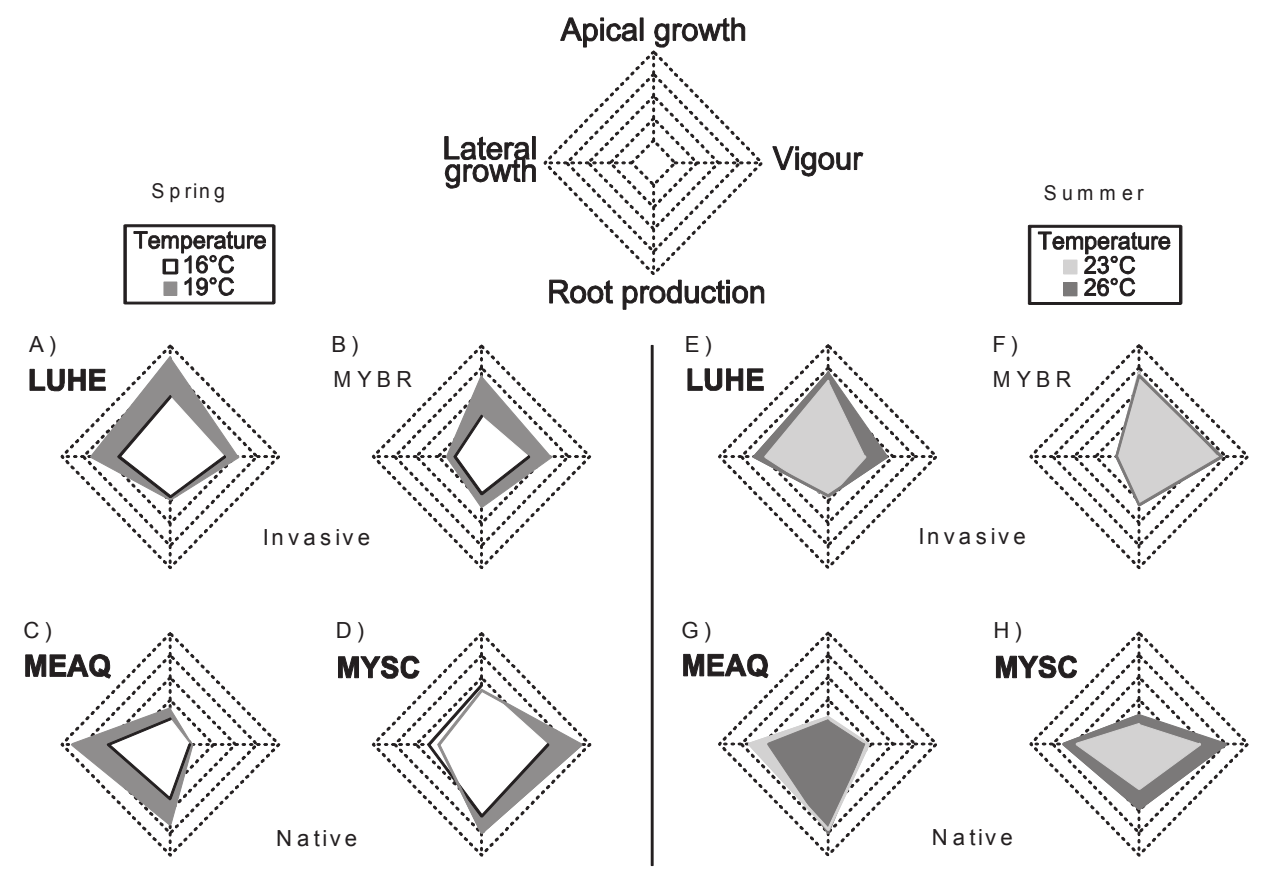



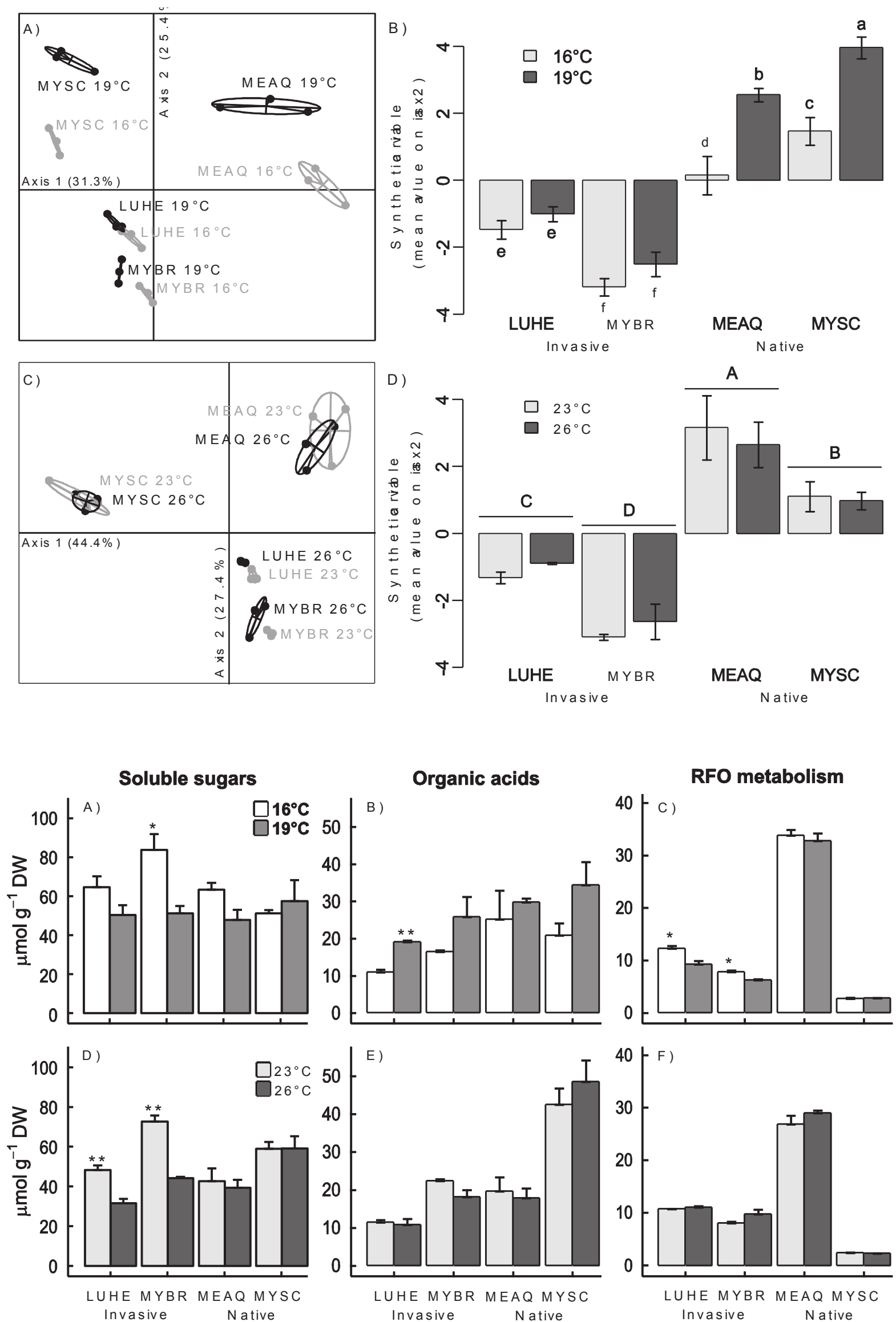
Table 1. Informations about the four amphibious species studied.

\begin{tabular}{|c|c|c|c|c|}
\hline Species & $\begin{array}{l}\text { Ludwigia hexapetala (Hook. \& Arn.) Zardini, } \\
\text { H.Y. Gu \& P.H. Raven }\end{array}$ & $\begin{array}{l}\text { Myriophyllum aquaticum (Vell.) } \\
\text { Verdc }\end{array}$ & Mentha aquatica $\mathrm{L}$. & Myosotis scorpioides L \\
\hline Synonym & $\begin{array}{l}\text { Ludwigia grandiflora subsp. hexapetala; } \\
\text { Ludwigia uruguayensis }\end{array}$ & Myriophyllum brasiliense & Mentha hirsuta & Myosotis palustris \\
\hline Common name & Waterprimrose & Parrotfeather & Water mint & Water forget-me-not \\
\hline Family & Onagraceae & Halogaraceae & Lamiaceae & Boraginaceae \\
\hline Native to & South America & South America & Europe & Europe \\
\hline Introduced or invasive in & $\begin{array}{l}\text { Europe, North america, Australia, New } \\
\text { Zealand, Turkey (Thouvenot et al., 2013) }\end{array}$ & $\begin{array}{l}\text { Europe, North america (Hussner et } \\
\text { al., 2009; Thiébaut, 2007) }\end{array}$ & $\begin{array}{l}\text { North America (USDA, } \\
\text { 2017) }\end{array}$ & $\begin{array}{l}\text { North America (USDA, } \\
\text { 2014) }\end{array}$ \\
\hline Photosynthetic pathway & C4 (Madanes et al., 2015) & $\mathrm{C} 3$ & $\mathrm{C} 3$ & C3 \\
\hline $\begin{array}{l}\text { Temperature } \\
\text { requirements }\end{array}$ & $\begin{array}{l}\text { Minimum temperature to initiate growth : } \\
12^{\circ} \mathrm{C} \text { to } 15^{\circ} \mathrm{C} \text { (EPPO, 2011) ; optimum } \\
\text { development between } 20^{\circ} \mathrm{C} \text { and } 30^{\circ} \mathrm{C} \\
\text { (Ruaux, 2008) }\end{array}$ & $\begin{array}{l}\text { Growth begin when water } \\
\text { temperature reach } 8^{\circ} \mathrm{C} \text { (Moreira et } \\
\text { al., 1999) }\end{array}$ & N.A. & N.A. \\
\hline
\end{tabular}


Table 2. Summary of ANOVA on morphological traits and transformed traits to a 10-day exposition to spring temperature $\left(16^{\circ} \mathrm{C}\right.$ and $\left.19^{\circ} \mathrm{C}\right)$. Different capital letters represent significant differences between species. Different small letters indicate significantly different interactions between species and temperature. Different capital letters represent differences between species. The symbol * highlights an overall temperature effect. $n s=$ not significant $(P<0.05$, Tukey HSD test $)$. Effect of species: $n=40, d f=3$; effect of temperature: $n=80, d f=1$; effect of species $x$ temperature interaction: $n=20, d f=3$.

\begin{tabular}{|c|c|c|c|c|c|c|}
\hline Traits & Effect & $\%$ sum sq & $F$ value & $P$ value & Tukey HSD & \\
\hline \multirow[t]{11}{*}{ RGR stem } & Species & 28.7 & 22.56 & $<0.001$ & & \\
\hline & Temperature & 8.6 & 20.20 & $<0.001$ & & \\
\hline & $\begin{array}{l}\text { Species } \mathrm{x} \\
\text { temperature }\end{array}$ & 4.9 & 3.84 & 0.011 & L. hexapetala $16^{\circ} \mathrm{C}$ & bc \\
\hline & & & & & L. hexapetala $19^{\circ} \mathrm{C}$ & a \\
\hline & & & & & M. aquatica $16^{\circ} \mathrm{C}$ & e \\
\hline & & & & & M. aquatica $19^{\circ} \mathrm{C}$ & de \\
\hline & & & & & M. brasiliense $16^{\circ} \mathrm{C}$ & cde \\
\hline & & & & & M. brasiliense $19^{\circ} \mathrm{C}$ & $a b$ \\
\hline & & & & & M. scorpioides $16^{\circ} \mathrm{C}$ & bcd \\
\hline & & & & & M. scorpioides $19^{\circ} \mathrm{C}$ & bcd \\
\hline & Residuals & 57.8 & & & & \\
\hline \multirow{4}{*}{$\begin{array}{l}\text { RGR fresh } \\
\text { weight }\end{array}$} & Species & 43.2 & 40.98 & $<0.001$ & L. hexapetala & B \\
\hline & & & & & M. aquatica & C \\
\hline & & & & & M. brasiliense & B \\
\hline & & & & & M. scorpioides & A \\
\hline
\end{tabular}




\begin{tabular}{|c|c|c|c|c|c|c|}
\hline & \multirow{3}{*}{$\begin{array}{l}\text { Temperature } \\
\text { Species } x \\
\text { temperature }\end{array}$} & \multirow[t]{2}{*}{5.0} & \multirow[t]{2}{*}{14.35} & \multirow[t]{2}{*}{$<0.001$} & \multicolumn{2}{|l|}{$16^{\circ} \mathrm{C}$} \\
\hline & & & & & $19^{\circ} \mathrm{C}$ & * \\
\hline & & 1.9 & \multirow[t]{2}{*}{1.83} & \multirow[t]{2}{*}{ ns } & & \\
\hline & Residuals & 49.9 & & & & \\
\hline \multirow{8}{*}{$\begin{array}{l}\text { Number of } \\
\text { roots }\end{array}$} & \multirow[t]{4}{*}{ Species } & \multirow[t]{4}{*}{21.9} & \multirow[t]{4}{*}{14.18} & \multirow[t]{4}{*}{$<0.001$} & L. hexapetala & $B$ \\
\hline & & & & & M. aquatica & A \\
\hline & & & & & M. brasiliense & B \\
\hline & & & & & M. scorpioides & A \\
\hline & \multirow[t]{2}{*}{ Temperature } & \multirow[t]{2}{*}{3.0} & \multirow[t]{2}{*}{5.92} & \multirow[t]{2}{*}{0.016} & $16^{\circ} \mathrm{C}$ & \\
\hline & & & & & $19^{\circ} \mathrm{C}$ & $*$ \\
\hline & $\begin{array}{l}\text { Species } \mathrm{x} \\
\text { temperature }\end{array}$ & 0.9 & \multirow[t]{2}{*}{0.56} & \multirow[t]{2}{*}{ ns } & & \\
\hline & Residuals & 74.2 & & & & \\
\hline \multirow{11}{*}{$\begin{array}{l}\text { Number of } \\
\text { lateral shoots }\end{array}$} & Species & 26.3 & 19.75 & $<0.001$ & & \\
\hline & Temperature & 3.5 & 7.84 & 0.006 & & \\
\hline & \multirow[t]{8}{*}{$\begin{array}{l}\text { Species } \mathrm{x} \\
\text { temperature }\end{array}$} & \multirow[t]{8}{*}{6.3} & \multirow[t]{8}{*}{4.77} & \multirow[t]{8}{*}{0.003} & L. hexapetala $16^{\circ} \mathrm{C}$ & c \\
\hline & & & & & L. hexapetala $19^{\circ} \mathrm{C}$ & $a b$ \\
\hline & & & & & M. aquatica $16^{\circ} \mathrm{C}$ & $a b c$ \\
\hline & & & & & M. aquatica $19^{\circ} \mathrm{C}$ & a \\
\hline & & & & & M. brasiliense $16^{\circ} \mathrm{C}$ & $d$ \\
\hline & & & & & M. brasiliense $19^{\circ} \mathrm{C}$ & $c d$ \\
\hline & & & & & M. scorpioides $16^{\circ} \mathrm{C}$ & $\mathrm{bc}$ \\
\hline & & & & & M. scorpioides $19^{\circ} \mathrm{C}$ & $c d$ \\
\hline & Residuals & 63.9 & & & & \\
\hline
\end{tabular}

Table 3. Summary of ANOVA on morphological traits and transformed traits to a 10-day exposition to summer temperature $\left(23^{\circ} \mathrm{C}\right.$ and $\left.26^{\circ} \mathrm{C}\right)$. Different capital letters represent significant differences between species. Different small letters indicate significantly different interaction between species and temperature. Different capital letters represent differences between species. The symbol* highlights an overall temperature effect. ns = not significant $(P<0.05$, Tukey HSD test $)$. Effect of 
species: $n=40, d f=3$; effect of temperature: $n=80, d f=1$; effect of species $x$ temperature interaction: $n=20, d f=3$.

\begin{tabular}{lllllll}
\hline Traits & Effect & \% sum sq & F value & P value & Tukey HSD & \\
\hline RGR stem & Species & 60.6 & 61.69 & $<0.001$ & L. hexapetala & A \\
& & & & M. aquatica & B \\
& & & M. brasiliense & A \\
& & & M. scorpioides & B
\end{tabular}

$\begin{array}{lllllll} & \text { Temperature } & 0.1 & 0.32 & \text { ns } & & \\ & \text { Species x temperature } & 0.6 & 0.58 & \text { ns } & \\ & \text { Residuals } & 38.7 & & & & \\ & \text { Species } & 25.9 & 14.46 & <0.001 & \text { L. hexapetala } & \text { B } \\ \begin{array}{l}\text { RGR fresh } \\ \text { weight }\end{array} & & & & \text { M. aquatica } & \text { B } \\ & & & & \text { M. brasiliense } & \text { A } \\ & & & & \text { M. scorpioides } & \text { A }\end{array}$

\begin{tabular}{|c|c|c|c|c|c|c|}
\hline & Temperature & 1.9 & 3.26 & ns & & \\
\hline & Species $x$ temperature & 2.9 & 1.59 & ns & & \\
\hline & Residuals & 69.3 & & & & \\
\hline Number of & Species & 27.4 & 15.28 & $<0.001$ & L. hexapetala & B \\
\hline & & & & & M. aquatica & A \\
\hline & & & & & M. brasiliense & B \\
\hline & & & & & M. scorpioides & B \\
\hline & Temperature & 0.4 & 0.63 & ns & & \\
\hline & Species $x$ temperature & 0.9 & 0.51 & ns & & \\
\hline & Residuals & 71.3 & & & & \\
\hline Number of & Species & 34.09 & 21.63 & $<0.001$ & L. hexapetala & A \\
\hline & & & & & M. aquatica & A \\
\hline & & & & & M. brasiliense & B \\
\hline & & & & & M. scorpioides & A \\
\hline & Temperature & 0.02 & 0.04 & ns & & \\
\hline & Species $x$ temperature & 3.40 & 2.15 & ns & & \\
\hline & Residuals & 62.49 & & & & \\
\hline
\end{tabular}


Table 4. Summary of ANOVA on synthetic values of carbohydrate content at $16-19^{\circ} \mathrm{C}$ and at $23-26^{\circ} \mathrm{C}$.

\begin{tabular}{llllll}
\hline Traits & Effect & df & \% sum sq & F value & P value \\
\hline Synthetic variable & Species & 3 & 84.34 & 309.66 & $<0.001$ \\
$16-19^{\circ} \mathrm{C}$ & Temperature & 1 & 10.26 & 112.99 & $<0.001$ \\
& Species x temperature & 3 & 3.95 & 14.52 & $<0.001$ \\
& Residuals & & 1.45 & & \\
\hline Synthetic variable & Species & 3 & 95.83 & 0.09 & $<0.001$ \\
$23-26^{\circ} \mathrm{C}$ & & & & \\
& Temperature & 1 & 0.02 & 154.31 & $\mathrm{~ns}$ \\
& Species x temperature & 3 & 0.84 & 1.35 & $\mathrm{~ns}$ \\
& Residuals & & 3.31 & & \\
\hline
\end{tabular}


Table 5. Individual soluble sugar content ( \pm SE) in Ludwigia hexapetala, Myriophyllum brasiliense, Mentha aquatica and Myosotis scorpioides, significantly different between $16^{\circ} \mathrm{C}$ and $19^{\circ} \mathrm{C}$ and between $23^{\circ} \mathrm{C}$ and $26^{\circ} \mathrm{C}$. (A) soluble sugars; (B) organic acids; (C) RFO metabolism. nd=not detected

\begin{tabular}{|c|c|c|c|c|c|c|c|c|}
\hline Species & Temp & $\begin{array}{c}\text { Fructose } \\
\text { (A) }\end{array}$ & $\begin{array}{l}\text { Glucose } \\
\text { (A) }\end{array}$ & $\begin{array}{c}\text { Sucrose } \\
\text { (A) }\end{array}$ & $\begin{array}{l}\text { Malate } \\
\text { (B) }\end{array}$ & $\begin{array}{c}\text { Glycerate } \\
\text { (B) }\end{array}$ & $\begin{array}{l}\text { Myo-inositol } \\
\text { (C) }\end{array}$ & $\begin{array}{l}\text { Galactinol } \\
\text { (C) }\end{array}$ \\
\hline Ludwigia & $16^{\circ} \mathrm{C}$ & $28.53 \pm 3.79$ & $15.44 \pm 2.92$ & $19.23 \pm 2.07$ & $6.69 \pm 0.59$ & $1.04 \pm 0.1$ & $5.30 \pm 0.08$ & $4.49 \pm 0.29$ \\
\hline \multirow[t]{2}{*}{ hexapetala } & $19^{\circ} \mathrm{C}$ & $19.82 \pm 1.86$ & $11.54 \pm 2.12$ & $17.75 \pm 1.81$ & $13.9 \pm 0.47$ & $1.57 \pm 0.14$ & $4.97 \pm 0.29$ & $2.53 \pm 0.21$ \\
\hline & & & & & $* * *$ & $*$ & & $* *$ \\
\hline Myriophyllum & $16^{\circ} \mathrm{C}$ & $43.66 \pm 4.89$ & $17.37 \pm 3.76$ & $19.04 \pm 1.53$ & $7.57 \pm 0.67$ & $4.69 \pm 0.42$ & $7.35 \pm 0.34$ & $0.04 \pm 0.04$ \\
\hline \multirow[t]{2}{*}{ brasiliense } & $19^{\circ} \mathrm{C}$ & $24.98 \pm 0.98$ & $11.02 \pm 1.09$ & $13.17 \pm 1.84$ & $10.01 \pm 2.12$ & $10.8 \pm 3.07$ & $5.76 \pm 0.23$ & $0.03 \pm 0.03$ \\
\hline & \multicolumn{5}{|c|}{$* * *$} & \multicolumn{3}{|c|}{$*$} \\
\hline Mentha & $16^{\circ} \mathrm{C}$ & $18.92 \pm 1.48$ & $25.08 \pm 2.71$ & $14.14 \pm 2.31$ & $9.96 \pm 4.6$ & nd & $5.18 \pm 0.23$ & $7.72 \pm 0.27$ \\
\hline \multirow[t]{2}{*}{ aquatica } & $19^{\circ} \mathrm{C}$ & $12.30 \pm 1.04$ & $17.80 \pm 6.74$ & $16.39 \pm 0.89$ & $15.2 \pm 3.38$ & nd & $5.99 \pm 0.92$ & $8.13 \pm 0.67$ \\
\hline & \multicolumn{3}{|c|}{ * } & & & & & \\
\hline Myosotis & $16^{\circ} \mathrm{C}$ & $11.35 \pm 0.77$ & $8.14 \pm 1.72$ & $29.87 \pm 0.77$ & $5.59 \pm 1.23$ & $0.47 \pm 0.23$ & $2.69 \pm 0.21$ & nd \\
\hline scorpioides & $19^{\circ} \mathrm{C}$ & $11.24 \pm 6.88$ & $8.25 \pm 5.12$ & $37.24 \pm 0.39$ & $16.38 \pm 6.06$ & $1.04 \pm 0.27$ & $2.83 \pm 0.06$ & nd \\
\hline Ludwigia & $23^{\circ} \mathrm{C}$ & $18.09 \pm 1.78$ & $9.77 \pm 0.26$ & $19.95 \pm 0.91$ & $8.05 \pm 0.45$ & $1.67 \pm 0.27$ & $4.77 \pm 0.09$ & $2.62 \pm 0.16$ \\
\hline \multirow[t]{2}{*}{ hexapetala } & $26^{\circ} \mathrm{C}$ & $6.34 \pm 0.95$ & $4.62 \pm 0.59$ & $20.18 \pm 0.66$ & $8.00 \pm 1.41$ & $0.81 \pm 0.07$ & $4.33 \pm 0.29$ & $2.73 \pm 0.004$ \\
\hline & & $* *$ & $* * *$ & & & & & \\
\hline
\end{tabular}




\begin{tabular}{|c|c|c|c|c|c|c|c|c|}
\hline Myriophyllum & $23^{\circ} \mathrm{C}$ & $41.02 \pm 2.19$ & $15.83 \pm 1.13$ & $14.94 \pm 0.24$ & $10.68 \pm 0.46$ & $8.34 \pm 0.25$ & $7.03 \pm 0.15$ & $0.32 \pm 0.10$ \\
\hline \multirow[t]{2}{*}{ brasiliense } & $26^{\circ} \mathrm{C}$ & $22.10 \pm 0.97$ & $7.82 \pm 0.27$ & $13.75 \pm 0.97$ & $9.06 \pm 0.62$ & $6.30 \pm 1.75$ & $6.92 \pm 0.35$ & $1.22 \pm 0.32$ \\
\hline & & $* * *$ & ** & & & & & \\
\hline Mentha & $23^{\circ} \mathrm{C}$ & $10.62 \pm 1.61$ & $18.02 \pm 4.13$ & $13.00 \pm 1.01$ & $8.99 \pm 1.92$ & nd & $4.86 \pm 0.42$ & $5.86 \pm 0.61$ \\
\hline aquatica & $26^{\circ} \mathrm{C}$ & $8.80 \pm 1.06$ & $16.85 \pm 2.49$ & $13.12 \pm 0.51$ & $7.01 \pm 0.80$ & nd & $4.86 \pm 0.27$ & $6.04 \pm 0.70$ \\
\hline Myosotis & $23^{\circ} \mathrm{C}$ & $6.37 \pm 0.84$ & $6.33 \pm 0.43$ & $45.40 \pm 4.50$ & $17.56 \pm 1.83$ & $0.59 \pm 0.11$ & $2.44 \pm 0.13$ & $0.01 \pm 0.00$ \\
\hline scorpioides & $26^{\circ} \mathrm{C}$ & $8.49 \pm 2.38$ & $7.23 \pm 1.79$ & $42.31 \pm 2.44$ & $26.37 \pm 4.78$ & $0.75 \pm 0.30$ & $2.19 \pm 0.19$ & $0.035 \pm 0.03$ \\
\hline
\end{tabular}

